Journal of the Textile Institute Proceedings and Abstracts

\title{
YORKSHIRE SECTION: Meeting at Bradford, 16th December, 1920. Mr. George Garnett in the Chair. SOME EXPERIMENTS IN THE MEASUREMENT OF NATIVE ABILITY AND ACQUIRED SKILL
}

\section{Henry Binns}

To cite this article: Henry Binns (1921) YORKSHIRE SECTION: Meeting at Bradford, 16th December, 1920. Mr. George Garnett in the Chair. SOME EXPERIMENTS IN THE MEASUREMENT OF NATIVE ABILITY AND ACQUIRED SKILL, Journal of the Textile Institute Proceedings and Abstracts, 12:1, 5-11, DOI: 10.1080/00405002108630984

To link to this article: http://dx.doi.org/10.1080/00405002108630984

曲 Published online: 24 Nov 2008.

Submit your article to this journal $₫$

山 Article views: 3

Q View related articles ¿ 


\section{PROCEEDINGS OF}

YORKSHIRE SECTION

Mecting at Bradford, $16 t h$ December, 1920.

Mr. Georas Garnems in the Chair.

SOME EXPERIMENTS IN THE MEASUREMENT OF NATIVE ABILITY AND ACQUIRED SKILL

\section{By Henny Brnas.}

Recent legislation has had the effect of bringing educationalists and business men into closer contact. The happiness of each individual is dependent upon a broed interpretation of the aims of education, and it is none the less true that the ability to earn a livelihood is an important factor in individual and national life. Acquired skill in industry is but a continuation of the dovelopment of native ability in the schools, and it may be well for business men and teachers to realise, more fully than has been the case in the past, that co-operation is more than ever necessary at those ages during which transference from school to industry takes place.

In rospect of young people botween the ages of twolve and twenty years, educational-industrial research is needed, in order to find out the true facts on an impartial basis. Much valuable work is being done in various parts of the world, because it is recognised that " some boys and girls are kept back to their lasting injury, ocoupied with intellectual pursuits beneath their capacity, solely because their perents and teachers are unaware of an inborn aptitude, while others whose powers are below normal are pressed forward and stimulated by reward or punishment to undertake tasks beyond their powers." It is necessary to determine whether a given child is unsuccessful in sohool because of poor native ability, or because of poor instruction, leck of interest, or some other removable cause.

Ability and skill are built upon intelligence, which is defined by Stern as " the general capecity of an individual to adjust his thinking to new requirements; it is general mental adaptability to new problems and conditions of life." Binet says :- "To judge well; to comprehend well; to reason well; these are the essential activities of intelligence."

In order to reproduce a cloth, it is first necessary to analyse every factor in construction. With the aid of the standard yard and the standard pound, it is possible to compare, with the aid of a microscope, the diameter of an 80 's merino with the width of a piece, or the weight of a square inch with miles of fabric. But there are other factors, such as appearance, handle, and colour, which are determined by skill without mochanical aid, and the resulting variations in quotetions are often considerable.

An investigator is early driven to effort to find some means of measurement for intelligence, native ability, and skill, so that some comparison may be made between them. An analysis of cloth demands a sound opinion on many properties of raw material, and the anslysis of maximum skill likewise demands

\section{THE INSTITUTE}

a sound knowledge of the raw mental material in the child. For various reasons, school examinations are not acceptablo as a basis for research purposes, and the most recent experiments in measurement are more concerned with ideas than response to persons or things. Business life is more concerned with things, production being associated, mainly, with the act of doing. Business men excel in the doing and performing of operations and in responding to persons, rather than in ability to oxpress ideas verbally, or to explain in writing how they do things.

Megsuroments of ability to perform, therefore, seem likely to be more productive than those associated with language. Just as it is well known that ohildren, according to their degree of intelligence, learn a great deal which is not directly taught in the schoolroom, so in business-lifo a great deal of skill which has not been technically taught is picked up in course of deily life.

Instead of narrating the invaluable work being done by educationalists and sciontists, I propose to confine attention to certain experiments conducted in Bradford.

\section{PART I. : NATIVE ABILITY IN YOUNG CHILDREN.}

Taking as a basis the work of Pintner and Paterson on doaf children, cortain modifications were made for group testing. Three representative results are given for eight experiments, the average percentage representing the measure of ability to perform. Sharp children are noted by teachers to perform the most elementary things worse than dull children (this is shown in "a " and "c," TableI.), but with increasing difficulty the results are proportionately reversed :-

TABLE I : TestS AND PERCENTAONS.

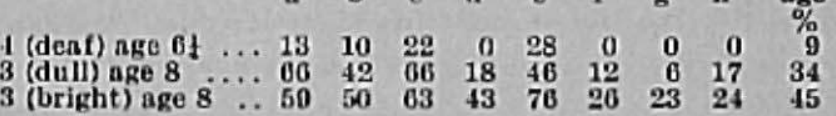

\section{PART II. : NATIVE ABIIITY IN SCHOOL,}

An everage result of a series of five types of tests, each of which can be performed by normal persons from eight years upwards, is suggestive.

(1) Srmple Motor Action : Taking what is known as a form board, a person is asked to place ten different shapes into their proper places on the board as quickly as possible. This is repeated three times, and the shortest time recorded as the measure. A deaf child of six took three minutes on the first trial, and reduced the time to 80 seconds on the third. An alert young woman has performed the same operation in 14 seconds, reducing this to 9 seconds. Leaving calculations aside, an observer cannot fail to be impressed with the effects of deafness and mental doficiency, as well as normal and supernormal activities. This test mensures a subject's "perception of difference in forms, powers of co-ordination in handling pieces, ability to learn 
by the oxporlonce of triel and auccess, and, boyond this, it may afford some gauge of the perception of the relntionship of object to object, of parts to the whole $\rightarrow$ a most valuable faculty in lifo."

(2) Qutok, Thобонтful ACtion : With same sized board, and with still ten pieces, tho subject is asked at a given signal to tako the ten pieces from an envelope and make ench fit into the board in the least possiblo time. For greater stability, the sverage of three different tests is taken for measurement. The ability to deal with an unknown but simple problem varies from a final average percentage of 21 in a sharp girl of 8 years, to $75 \%$ in a brilliant university student. Six baokward boys of $12 \frac{1}{2}$ years nveraged $31 \%$, whilst six good at sehool work sveraged $43 \%$ at the same average age. A boy of 14 years, who could not read, scored $31 \%$. Although attempts have been made to discriminate betweon full and half-timers by this means, no evidence for or against is available, nativo intelligence appearing to be the governing factor.

(3) Probles Action: A problem nction is introduced with seme sized board and ten pieces. Tho subject thinks he sees the solution instently, and acts, but finds the pieces do not fit. Some persons immediately see the impossibility and begin again, ultimately finding the correct solution. Others, ofter ten minutes' study, still fail to see the absurdity of the position. It has seemed to me that, for some, reason which needs explanation, the children in en elementary boarding school respond better than the children in the elementary day schools. In four classes in such a boarding school, the averages were as follows :-

$\begin{array}{lrlrllll}\text { Age } & 10 & \ldots & 12 & \ldots & 133^{2} 2 & \ldots & 131^{\frac{1}{2}} \\ \% & 9 & \ldots & 31 & \ldots & 38 & \ldots & 51\end{array}$

The highest score in several day schools has been $32 \%$ for a boy aged 14. In a group of 18 children, aged $12 f$, not one score was made, and these facts give us something that requires explanation.

Constructive problems of the same type seem to be impossible of solution in any elementary school, but are useful in connection with secondary and technical training. These appear to discriminate in favour of a constructive and engineering type of mind. "Factors best described as intelligence factors contribute primarily to superior ability in complex motor tests. Although the intelligence elements function in these reactions, they do so largely in an unconscious manner."

(4) Capacity to Follow Instructions : On entering business-life, a boy or girl has first to understend the necessity of following instructions without continual repetition of them. This type of measurement takes a prominent place in all recent investigations, and seems to have a greater bearing on business-life then on school-life. A subject is told on a given signal to turn over a sheet of paper, on the reverse gide of which is printed matter with 25 blanks, each one of which he lias to fill in as instructed. Remarkable difieronces in individuals, both in accuracy and time, are noticed. Sharp children of 8 years have recorded $39 \%$, and smart business men $78 \%$, with occasional scores up to $87 \%$. But age appeers to have little to do with this type of ability. Six backward boys, already referred to, varied from $0 \%$ to $52 \%$, with an average of $33 \%$; six good at achool work, of the same age, varied from $51 \%$ to $86 \%$, with an average of $71 \%$. Obsorvation in this connection leads one to appreciate the pationce oxhibited by teachers. Just the same difficulties as business mon complain of seem to be present in the schools, and it may be that the teacher can no more produce a normal mind in some children than a business man can make a manager of every boy entering his employ. On the other hand, the exceptionally keen and alert to such tests appear to be those one would like to employ in business.

(5) Frxity of Atrention: It is noxt desired to measure the acts of discrimination involved in selecting certain chosen digits from a sheet of mixed figures. and also the motor action in marking the digits with a pencil. Teachers agree, and the tests seem to show, that at 12 years of age there is a maximum speed and accuracy ability. Twenty children of this age averaged $79 \%$, whilst similarly trained children at 13 and 14 years averaged $\mathbf{7 3} \%$ and $\mathbf{7 6} \%$. Exceptional adults have gained $84 \%$. Backward boys of 14 reached $66 \%$, against $71 \%$ by normal boys. Simple acts of dis. crimination, repeated, show little variation between dull and normal children. Many operations of this nature do not call forth the mental problems involved in Tests 2, 3, and 4, but they do demand fixity of attention.

Frnal Result: The average of five types of test represents the intelligence employed in manipulating things as distinct from response to ideas or to persons. Language is only used in one test, and, though it seems to separate knowledge from intelligence, the knowledge factor is almost entirely absent. From a normal child of 8 years with a percentage of 25 , gradations can be measured to about $70 \%$ for a good adult, and $80 \%$ for a very good adult, whilst $90 \%$ would be super-normal. The literary mind may be high in school-work, but low to such tests. Some, with less literary ability, may accomplish practical work very well. Children requiring a second period to qualify for promotion stand high in school marks at the end of that second period, but these particular tests measure their native ability, and their scores are low. Broadly speaking, there are all-round students who do very well at both literary and handwork, and those who do badly at both. The former cannot be held back, nor the latter pushed forward; but the majority, being neither the one nor the other, might be considerably helped by their teachers if more accurate mensurements of abilities were available, and school-leaving reports could be made more useful from the business point of view.

Some group averagea are appended for comparison :-

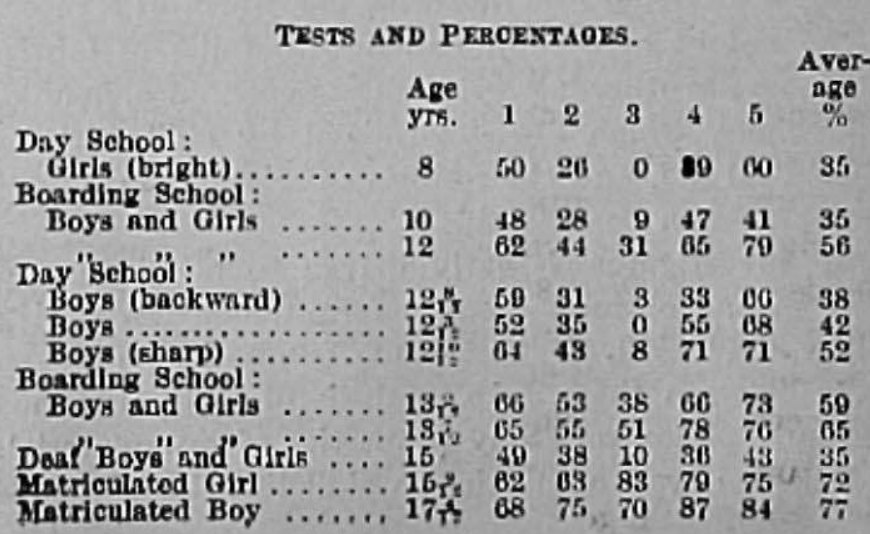


PART III. : NATIVE ABILITY AND ACQUIRED SKILL IN THE WOOL TRADE.

Whatever opinion may be formed about the montal age lovel of ehildren or adults, it is "improbable that dovolopment as a whole is completed at any particular age, oither for individuals or on the average. Emotional development, maturity, skill, acquisitions, aptitudes, and the like probably continue to develop indefinitely." Training and experionce have the effect of merging native ability into acquired skill until, finally, they are difficult to separate.

Wool Quatite Standands: Measurements of asquired skill on wool and its fabrics are complicated by reason of the fact that there are several standards :-(1) the nominal trado standard; (2) the firm's standard; (3) the individual's standard; (4) variations within tho individual due to physical and montal changes. In ordinary trading there is no physical standard by which quality or yield can be definitely ascertained. It was necessary, therefore, to accept some nominal trade standard. The War Department Quality and Country of Origin answored this purpose, the Bradford Conditioning House standard tests for yield being also adopted. Fifteen qualities from 40 's to 80 's were judged in the greasy and scoured states, two of these samples being specially selected because of their sandy and deceptive nature. In order to show measurements of judges accustomed to handling a specific type of wool, five merinos were selected as an example for comparative purposes, and a final measure in percentage given, based on one quality, representing $20 \%$.

In one case of great accuracy of judgment during dry weather $(96 \%)$ the percentage was reduced to 84 in wet weather 14 days later. Again, a taker-off of 17 years' experience with high accuracy (again 96\%) had working with him two sorters of 13 and 7 years' experience respectively, the former showing an underestimation in every instance, amounting to about $20 \%$, and the other an over-estimation to about the same extent.

In the case of an individual holding a most responsible position, the wesring of glasses sppeared to alter judgment considerably, whilet in another case judgment was very much improved by a subsequent visit to an optician. In the case of a student of 3 years' experionce, $92 \%$ was recorded, whilst a student with one year of exporience (intensive) reached $94 \%$, but a qualifiod man who had ceased practising for 18 years only recorded $74 \%$.

Yield already allows of measurement by percentage, which need not be laboured here. The highest skill was represented by the steadiest yields on qualities familiar to the judge, who, however, made wider estimations on unfamiliar qualitios, as might be oxpocted. Students and woolsorters without experienco (practical) averaged from $10 \%$ to $14 \%$ error.

Country of Oriorn: Ability to decido the country of origin is most valuable. Ono jüdge named all samples correctly ; $85 \%$ to $90 \%$ seems to be very sound judgment. A good "quality" and "yield" judge only recorded $66 \%$ on " origin," whilst an inexperionced student judged $53 \%$ accurately.

GREASY AND SCDURED WOOLS: Though admitting that group averages are most decoptive, they serve as an indication of tendencios. The following show the veriations :-

(a) selected individuals on selected qualities,

(b) all individuals experimented upon every quality with which they were unfamiliar, as woll as their specialities, studonts boing placed in their own groups.

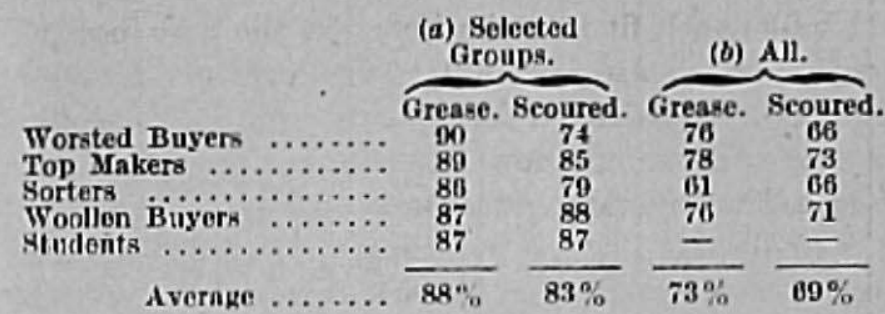

Judgrent os Grease AND Scoured : Buyers for worsted do not handle scoured wool, whilst buyers of woollens do so in varying degree. Thus a worsted buyer scored $92 \%$ grease and $54 \%$ scoured, against $76 \%$ grease and $92 \%$ scoured by a woollen buyer. Top makers' records wore steadier for the reason that they handle wool in both states. The records showed that the general lovel of quality accuracy is incrensed by experience on epecific types of wool.

NATIVE ADILTY v. ACQUiRed SKIIL ON SCOURED Wool: Scoured wool gives an opportunity for comparison between native and acquired ability. In the case of the skill now enumerated, allowance should be made for the fact that most of the judges had been accustomed to greasy wool. The native ability recorded is by children of 12 years of age to ladies of 40 years, all inexperienced in handling wool. The test consisted in (a) grading ten scourod qualities of War Depertment Standerd, $40^{\prime}$ s to $80^{\prime} \mathrm{s}$; (b) replecing selected samples on their proper qualities; and (c) grading by touch alone.

\begin{tabular}{|c|c|c|c|c|c|c|c|}
\hline & & (a) $\mathrm{C}$ & rading. & (b) & lection. & (c) & Гouch. \\
\hline S. & N. & Skill & Native & Śkıll & Natlve & SkIll & Native \\
\hline$\frac{1}{2}$ & 2 & 80 & & 70 & & 90 & 70 \\
\hline 3 & 4. & 00 & 80 & 00 & 90 & 70 & 90 \\
\hline 5 & 0 & 90 & 80 & 90 & 90 & 80 & 50 \\
\hline 7 & 8 & 00 & 40 & 75 & 85 & 60 & 10 \\
\hline 9 & 10 & 70 & 70 & 70 & 65 & 80 & 80 \\
\hline 11 & 12 & 100 & 100 & 70 & 70 & 70 & 30 \\
\hline 13 & 11 & 90 & 60 & 80 & 50 & 70 & 90 \\
\hline Avernge & $\%$ & 87 & 73 & 78 & 71 & 74 & 60 \\
\hline
\end{tabular}

Characteristio Difference in Skinl : The average differences are not so great as might be expected. A familiar tendency in all experiments is again noted, c.g., that the highest skill shows a steadiness not present in the untrained. The differences between the maximum and minimum scores in each group are :-

\begin{tabular}{|c|c|c|c|c|}
\hline $3 \mathrm{kil}$ & $\begin{array}{l}\text { Group } \\
\text { (a) } \\
20\end{array}$ & $\begin{array}{c}\text { Group } \\
\text { (b). }\end{array}$ & $\begin{array}{c}\text { Group } \\
\text { (c). } \\
30\end{array}$ & $\begin{array}{c}\text { Average } \\
\% \\
2\end{array}$ \\
\hline & & 40 & 80 & 60 \\
\hline
\end{tabular}

TOPS : Tops wore again standards from the War Department qualities, 30 samples being judged for sight, touch, sight and touch together, and " full trade " judgments. Two officials of the Dopartment (" $\mathrm{a}$ " and " $\mathrm{b}$ "), who were in daily touch with the majority of the goods experimented upon, very kindly assisted. A good many experienced buyers and some students also gave time. For the purpose of this enquiry, the judgments of six persons were taken, the total accurncy being represented in percentages, together with over (plus) and under-estimation (minus) 
of War Dopartmont standards. "A" undertook exporimonts whon montally disturbod, and also when in a good buying humour. Seconds per unit of judg. mont are also apponded.

\begin{tabular}{|c|c|c|c|c|c|c|c|c|}
\hline$\hat{\mathrm{E}}$ & 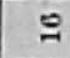 & & 일 & $\exists$ & 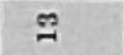 & & & \\
\hline 局 & $\begin{array}{l}+0 \\
+1 \\
8\end{array}$ & $\vdots$ & $\begin{array}{l}90 \\
\pm 1 \\
1\end{array}$ & $\begin{array}{l}+01 \\
+1 \\
\overrightarrow{0}\end{array}$ & $\begin{array}{l}+a \\
+1 \\
\text { id }\end{array}$ & & $\vdots$ & \\
\hline$\widehat{\mathrm{E}}$ & $1 \%$ & $\Rightarrow$ & $\stackrel{ }{\circ}$ & 익 & 85 & & $\cong$ & \\
\hline ప్ & $\begin{array}{l}\infty \infty \\
+1 \\
\infty \\
\infty\end{array}$ & $\begin{array}{l} \pm 0 \\
+1\end{array}$ & $\begin{array}{l}901 \\
\pm 1 \\
0\end{array}$ & $\begin{array}{l}+\infty \\
+1 \\
\infty\end{array}$ & 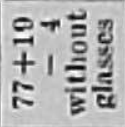 & $\begin{array}{l}-10 y \\
+1 \frac{9}{2} \\
-1\end{array}$ & $\begin{array}{l}\text { 여어 } \\
+1 \\
\vdots \\
\vdots\end{array}$ & $\begin{array}{l}50 \\
70 \\
0 \\
0\end{array}$ \\
\hline$\widehat{E}$ & $\bar{z}$ & 0 & $\cong$ & $\stackrel{2}{\sim}$ & $\vec{~}$ & & 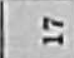 & \\
\hline ฮี & $\begin{array}{l}\frac{1}{7}= \\
\pm 1 \\
\frac{1}{5}\end{array}$ & $\begin{array}{l}-10 \\
+1 \\
\text { 1 }\end{array}$ & $\begin{array}{l}\infty \\
+1 \\
\infty \\
\infty\end{array}$ & $\begin{array}{l}0,0 \\
+1 \\
0\end{array}$ & $\begin{array}{l}920 \\
+1 \\
0^{2}\end{array}$ & $\begin{array}{l}\infty \\
+1 \\
0\end{array}$ & $\begin{array}{l}+01 \\
a^{\circ} \\
\pm 1 \\
\mathbb{2}\end{array}$ & $\begin{array}{l}80 \\
81^{\circ} \\
\pm 1 \\
i\end{array}$ \\
\hline$\dot{E}$ & : & $\stackrel{-}{\circ}$ & $\cong$ & \pm & bे & & $\stackrel{\infty}{\sim}$ & \\
\hline 㟧 & $\begin{array}{l}\text { 윰 } \\
\text { +1 } \\
\text { ह }\end{array}$ & $\begin{array}{l}n \\
+1 \\
8\end{array}$ & $\begin{array}{l}\infty \infty 0 \\
+1 \\
05\end{array}$ & $\begin{array}{l}\infty \infty \\
+1 \\
\infty\end{array}$ & $\begin{array}{l}-9 \\
+1 \\
+1 \\
=\end{array}$ & 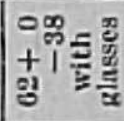 & 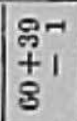 & 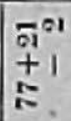 \\
\hline & 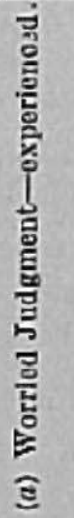 & $\begin{array}{l}\text { 号 } \\
\text { E. } \\
\text { 总 } \\
\text { E } \\
\text { E }\end{array}$ & 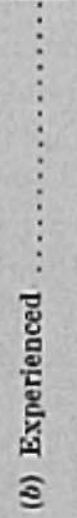 & 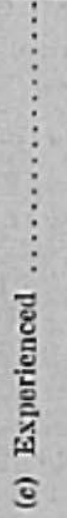 & 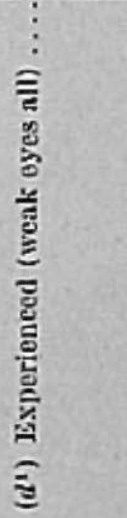 & 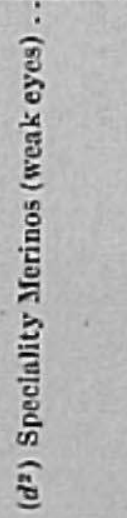 & 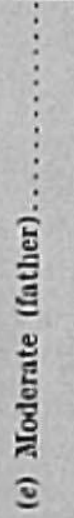 & 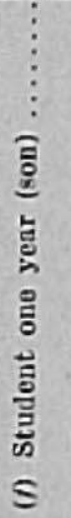 \\
\hline
\end{tabular}

Individual Differences in Judgarent : The following observations are suggested by the foregoing records :-

(a) The difference between worried and calm judgmont is represented by a narrowing of extremes of error ; by greater accuracy ; quicker time.

(b) A very sound judge, because of the independent accuracy of the senses in conjunction with a good full judgment. This would be valuable in adverse climatic and mental conditions.

(c) A very accurate full judgment, but decidedly weak on touch.

(d $d^{1}$ Was disturbed by lower qualities with which ho was not familiar; and on his speciality $\left(d^{2}\right)$ his glasses appeared to affect judgment, whilst his touch was high.

(c) and $(f)$ Father and son trained quite independently and only have relationship in common. Show characteristic over-estimation, possibly the result of a temperamental, optimistic spirit. Touch in (e) is higher than sight or both; a keen hobby has doubtless trained touch.

Experiments on born-blind ladies over the same samples showed remarkable discrimination as to fine differences, merinos being placed exactly in order of quality, though this does not seem possible by touch alone in the trade.

YARNS : Thirty samples, ranging from 2/16 32's to $2 / 6080$ 's were willingly supplied by three large firms of ropute in the district. These wero judged for quality, counts, and turns per inch. In the initial oxperimonts, the yarns were takon in haphazard manner, but shortly aftorwards methods suggested by Mr. Bartlett, in connection with the Admiralty submarine work, were adopted with advantage. Commencing with the lowest quality, an irregular rise to the finest quality was presented, followed by a downward movement. Duplicatos of the first samples were inserted at intervals, in order to check judgment. A selection of five qualities and duplicates taken from the complete list may serve to illustrate the results cbtainod.

Six judgments by each of two buyers, agents, and technically trained spinners, give a representativo idea of trade skill. The final rasults of measurement in percentages, showing the deviation from (1) the person's own judgment, (2) the firm's standard, and (3) response to personal suggestion, aro as follows, and attached is also tho individual's estimation early in the test, compared with his estimation towards the close :-

\section{FINAL JUDGMENT ON $80^{\circ} \mathrm{s}, 70^{\prime} \mathrm{s}, 64^{\prime} \mathrm{s}, 40^{\circ} \mathrm{s}$, 4 SD $36^{\prime} \mathrm{s}$}

\begin{tabular}{|c|c|c|c|c|c|}
\hline \multirow{2}{*}{ 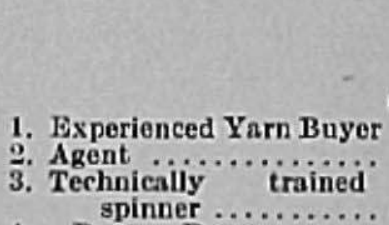 } & \multicolumn{3}{|c|}{$\begin{array}{l}\text { From Own } \\
\text { Standard. }\end{array}$} & Aver- & $\begin{array}{l}\text { Resist- } \\
\text { ance to } \\
\text { Sugges- }\end{array}$ \\
\hline & $\begin{array}{l}\text { Qual. } \\
88 \\
88\end{array}$ & $\begin{array}{l}\text { Count } \\
86 \\
78\end{array}$ & & $\begin{array}{l}5 \quad 8 \\
80 \\
82\end{array}$ & $\begin{array}{l}\text { tion. } \\
00 \\
00\end{array}$ \\
\hline 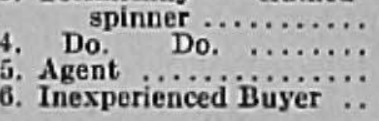 & $\begin{array}{l}88 \\
88 \\
96 \\
28\end{array}$ & $\begin{array}{l}72 \\
78 \\
80 \\
68\end{array}$ & $\begin{array}{l}86 \\
84 \\
04 \\
56\end{array}$ & $\begin{array}{l}83 \\
86 \\
85 \\
50\end{array}$ & $\begin{array}{l}90 \\
95 \\
80 \\
70\end{array}$ \\
\hline $\begin{array}{l}\text { Experienced Yarn Buyer. } \\
\text { Agent } \\
\text { Technically } \cdots \ldots \ldots \ldots \ldots \\
\text { trained }\end{array}$ & $\begin{array}{r}\text { Fro } \\
\text { Qu } \\
8 \\
8\end{array}$ & & & $\begin{array}{c}\text { andard. } \\
\text { Turns } \\
74 \\
85\end{array}$ & $\begin{array}{c}\text { Average } \\
\% \\
83 \\
86\end{array}$ \\
\hline 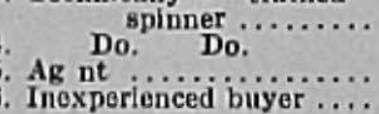 & & & & $\begin{array}{l}91 \\
73 \\
57 \\
30\end{array}$ & $\begin{array}{l}85 \\
77 \\
78 \\
34\end{array}$ \\
\hline
\end{tabular}

Churacteristics of Good aNd Poor Judges: It may be observed that :-

(1) Two measures are possible-one showing the deviation from the standard, and the other from the judge's previous opinion. In both cases, the over and under-estimation are recorded :

(2) There are obviously fivo good judges, and one poor.

(a) $88 \%$ to $96 \%$ good, and $28 \%$ poor from own judgments.

(b) $82 \%$ to $89 \%$ good, and $50 \%$ poor from the standard range.

(3) There is a very high correlation between good judgment of the standard and one's own judgment, and a very low correlation in the case of the poor judgment.

(4) Tunss : In the estimation of turns, there is a marked tendency to over-estimate the standard. No. 3 has special lenowledge of turns, being a practical and technical expert. Probably, mechanical testing has reduced skill in turn estimation.

(5) Fatiaue : On quality, the figures show a tendency, in the sound judgments, to be higher or lower as fatigue sets in according to individual differences.

(6) Stgaestion : Good judges aro not suggestible. In business life, No. 6 could readily be made to believe a sample one quality batter than it was. On the other 
hand, No. 4 would bo especially diffeult to infuence as a buyer.

DYED CLOTHS : Tho samples used wore most carefully produced under controlled conditions, and wore examined by fifty persons in ton trado soctions. Though woven and dyed alike, the samples showed very minuto differences caused by combing, drawing, and spinning only. As this constitutes a besis of another enquiry. details may with advantage be omitted on this occasion.

Three good and three poor judges of observation and technical knowledge are contrasted in what can be regarded as a most difficult test.

Obsorvation.

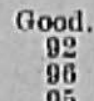

92
96
05

Fair.
77
83
70

Technlenl Knowledge.

$\begin{array}{cc}\text { Good. } & \text { Fair. } \\ 71 & 37 \\ 65 & 33 \\ 04 & 37\end{array}$

As in other oxperiments, good judges show high figures, whilst indifferent judges are not able to discriminate in regard to minute differences presented. Several ladies and gentlemen not in the trade attempted to grade the samples, bur all found it impossible. Acquired skill far exceeded any native ability.

BURLING AND MENDING : This serves as an illustration of native ability, on which acquired skill may be based. The experiments were intended to measure accuracy and neatness of aim, speed of action, quick colour judgment.

The subjects were instructed (1) to pull pins from a cushion with burling irons as quickly as possible; (2) to sort a pack of cards having ten difforent tints; (3) to name each colour aloud from a card, and, at the same time, to touch the same colour placed on the table; (4) to prick certain points on a paper with a pin.

The tests show that a qualified teacher of burling and a highly skilled burler compare very favourably with slow or indifferent, but practised, burlers. The records of five individuals are as follows :-

$\begin{array}{ccccccc}\text { Test } & 1 & 2 & 3 & 4 & \begin{array}{c}\text { Aver- } \\ \text { age }\end{array} \\ \text { (a) Qunlified tencher of } \\ \text { burling and mending . }\end{array}$

Without wishing to draw hasty conclusions from these figures, they do appear to represent variable trained ability in $a, b$, and $c$, with lack of native ability in $d$, and known native ability in $e$. The erratic movements of $d$ were in strong contrast to the steady and graceful movements of $a$.

COLOUR MATCHING : This was tested from two excellent trade Shade Cards of non-mercerised cotton, issued to the trade by Messrs. J. \& P. Conts Ltd. From one of these cards, twenty difficult tints were selected, and mounted on a separate card. Twonty-five porsons, viz., (1) tenchers of art; (2) wholesale and retail buyers, manufacturers, dyers, agents, merchants; (3) ladies not in the trade; and (4) elomentary school childron. Each person solected twenty tints from a total of 320 on the shade card. The test may be regarded as a difficult ono. Counting $5 \%$ for esch accuratoly selected, and $2 \frac{1}{2} \%$ for acceptable trade substitutes, there was a maximum limit of $90 \%$, and a minimum of $47 \%$. Timo occupiod varied from 17 seconds per unit of judgment to 72 seconds. The highest and lowest records in percentages in each group wero as follows :-

\begin{tabular}{|c|c|c|c|c|}
\hline & \multicolumn{2}{|c|}{ Accuracy : \% } & \multicolumn{2}{|c|}{$\begin{array}{c}\text { Time. (Secs, } \\
\text { persons.) }\end{array}$} \\
\hline & $\begin{array}{c}\text { Highest. } \\
85 \\
90 \\
80 \\
72\end{array}$ & $\begin{array}{c}\text { Lowest. } \\
72 \\
47 \\
65 \\
47\end{array}$ & $\begin{array}{c}\text { Highest. } \\
24 \\
30 \\
20 \\
70\end{array}$ & $\begin{array}{c}\text { Lowest. } \\
45 \\
57 \\
30 \\
72\end{array}$ \\
\hline
\end{tabular}

It will be noted that accuracy and time do not necessarily go together. In the case of one person of known ability, an unaccountably low score of $\mathbf{4 7}$ was made, which was found out six months later to be an indication of the beginnings of a nervous breakdown. This offect has been noted in connection with other experiments, and opens up a medical question of some interest. On the other hand, a girl of 12 years of age, with known artistic ability, recorded $72 \%$, which encouraged the headmaster to secure her admission into an art school.

THE INVALUABLE MEMORY : Experiments on the highest skill continually reveal the importance of memory as against comparative judgment. The tendency of the practical mind is to act rapidly, which, in effect, means relying on memory; the scientific mind seoks a physical and exact standard, which, obviously, is a slow process. It would be folly to under-rate the velue of mechanical eppliances. Whereever they can be employed, the better will be the result. But circumstances, in the main, favour rapid action. The analytical constructor of cloth must, of necessity, make every use of such appliances, but the wool-buyer and commercial traveller, for example, would be hampered by their use.

Tests fon Sight-Menory : Tests on minute differences of sight-memory reveal striking festures. The general lovel in the trade is about $65 \%$, with variations downwards to $45 \%$, and upwards, in very exceptional cases, to $95 \%$. One person with an extraordinary visual memory scored $100 \%$, and three hours afterwards $95 \%$, without the knowledge that the test would be repeated. Similarly, mind-memory is revealed daily by many of our leading business men, who do not make the copious notes so common with others. The value of memorising is to touch and smell is also obvious.

Memory TrainNo : Such experiments call attention to the necessity for training in these different types of memory. Business men with excellent memories for standards, and who are temperamentally quick, are. to say the least, most difficult to compete with,

\section{PART IV. : RESPONSE TO PERSONS.}

The previous allusions to suggestion indicate in a very small way the re-action of one mind to another. The practical application of this in business is too well known to Bradford gentlemen to need emphasis. As buyers, a strong resistance to suggestion is most 
important, but, as sellors, the future may requiro abilities of persunsion as woll as knowledgo of goods.

Cimaracteristics of Commerciat Travellens: A fow experiments mado with gentlemen whose sole occupation is solling show a rapid response to a great variety of awkward and difficult situations. One oxperiment consisted in the careful preparation of 25 brief questions, which wero to be answered instantly and without time for thought. One clever commercial gave 24 answers which could bo accepted as correct; some were not the stereotyped answers expected, but wore of such an original nature as would hnve mot the circumstances admirably.

RApid OBsenvation AND Adaptability: Tests on memory-individuals suddenly asked to close the oyes and deseribe surroundings-indicated that observation, consciously or unconsciously, had been acute. Similar tests on men with only slight experience showed an accurate response to only 5 to 10 questions, with no originality or adaptability. Observation was very superficial also.

If such experiments were extended, it might lead to more attention being paid to selling ability, both native and acquired. Whilst it is, perhaps, porfectly true that travellers are born and not made, that is all the more reason why we should find the born ones.

\section{CONCLUSION :}

Fine discriminations require accurate measurements, and are not of much value on a rapidly fluctuating market. But when values are steadier, and the difference of a small percentage in efficiency is important to this c)untry, then some of the methods suggested may be worthy of consideration. The status of skill has declined, and any means of restoring it should be welcomed.

The cost of education has increased, and will continue to increase. One remedy may be found to be in increasing the individual ability to produce the most perfect goods, and, at the same time, by education and other means, to widen the outlook on life for leisure hours. Combinod educational-industrial resenrch should result in better use being mado of native sbility and acquired skill, and, thereby, in the reduction of the per-head cost of national education. The attitude of the Bradford Education Committee, by encouraging such work amongst teachers, is an indication of the importance attached to indopendent inquiry.

May I pay a most heartfolt tribute to tho courtesy and unfailing kindness with which an amateur's exporimonts have been received. It would be impossible adequately to express in words the feelings of sympathy which both teachers a :d business mon have shown. Beneath an apparent determination to look after the more material affairs of life only, there is a far wider appreciation of knowledge for its own sake than many poople suspect, and which must be a valusble national asset in the future.

\section{Discussion.}

The Chamran said the lecturer had given an oxcollent survey of a most important study, and his remarks had been immensely interesting.
Mr. BrNes said it seomed to bo agrood that in the dny schools, with the largor clnsses, the instruction must necessarily be more in the character of drilling, with the consequence that in the mechanical things of life they got better results from the olementary school children. When they came to the difficult and complicated problems, however, and the children had to solve them for themselves, the boarding school children appeared to come out best. He was told that it was exceedingly difficult to get the elomentary day school teacher to fit in with the boarding school scheme.

A speaker stnted that the better boarding schools trained their own teachors. Pupils were sent to the University, and lafer thoy returmed to tho schools as probationer's for a year or so. They were then taken on the teaching staff or were appointed to a similar school. The procedure was very similar to the pupil teacher system of the elementary schools. He had found that the atmosphere of the boarding school was very different to that of the day school.

Prof. Ewant (Edinburgh) said that in Scotland they were of opinion that day-school children had a better idea of things than had boarding school children. He would bo glad to know what the lecturer intonded by the term "native" ability. Did he mean Bradford ability, English ability, or in-born ability ?

The LECTURER replied that the term implied " inborn" or "inherent" ability. At the same time, he was of opinion that there was a latent ability to be found in the woollen districts that would not be found, say, in a district given over to engineering.

Questioned as to whether he had found any difference between boys of sixteen who had started work as halftimers, and boys of the same age who had attended school full-time, the lecturer said he dealt with boys and girls as half-timers, and thought that if they took a very sharp boy as a half-timer he would be very sharp as a full-timer. It was determined largely by intelligence.

Mr. F. W. Rrchandson, F.C.S. (Bradford), referred to the experiments regarding burling and mending, and said the question of eyesight was one of the chief factors. If they took two equally intelligent girls, one troubled with astigmatism and the other with good eyesight, they would give very different results when tested. It would have been better to have reduced them to an equal by giving them the proper glasses before the experiment. The girl with the good seeing oyes would be able to spot the things at once and be in a good position.

A speaker said he had noticed that in a number of cases where boys and girls had been supplied with glasses they had developed an impatience, and had become bad spellers.

Prof. Ewart (Edinburgh) said it was an experienco of American teachers that black boys wero sharper than white boys up to a certain age, but that afterwards they foll right away.

The Chatrins remarked upon the difierence between the English and German systems of education, which seomed to give to the German that closer application to patient, scientific work. 
The LECTORER, in reply to further questions, said his experiments were yet only in the initinl stages.

Mr. G. R. GuUNx (Farsley) proposed a voto of thanks to the lecturer, and Mr. Join F. WIITte (Bradford) reconded, and said the oxperiments Mr. Binus had made might point out lines on which other investigation might be carried out.
The vote was heartily accorded, and Mr. Brwss, in reply, said that if his remarks had stimulated thought upon the lines he had taken he would be exceedingly glad. Anything they could do for the bonefit of industry would be done. There was a tremendous amount of enthusiasm existing on all sides, and this fact was now being more fully realised.

\section{GENERAL PROCEEDINGS, AND REPORTS}

\section{EMPIRE COTTON GROWING COMMITTEE : FUTURE ORGANISATION}

The Empire Cotton Growing Committeo is now in a position to outline the executive organisation it considers necessary to carry out the objects recommended in its main report published in January, 1920 (Cmd. 523). Most of the funds will be spent abroad in cotton growing countries, and in order to carry out ndequately the work which the Committeo is convinced must be dono to stimulate cotton cultivation, an annual sum of $£ 200,000$ is needed.

The work which, according to the report of January, 1920, must be done, falls into three groups. Group I. will be mainly administrative in character and will include :-Questions nffecting general policy, finance and establishment; correspondence with, advice to, nnd information from Government Departmepts, Local Administrations, Agricultural Departments and individual planters in cotton growing areas; organising and carrying through pioneer werk in suitable areas and bringing cotton growers and other workers on cotton growing together by dissemination of informs. tion and by providing them with facilities for keeping sbreast with progress and development throughout the world. Group II. will include :-Keeping abreast of, indexing, \&c., information on all scientific and experimental work on cotton growing; collecting full knowledge of the characteristics of all varieties of cotton; keeping in close touch with the British Cotton Industry Resorrch Associntion and fostering actual rosearch on cotton growing by establishment of cotton research stations abroad and staffing these; work of a commercial character, such as valuing cottons and keeping in touch with all markets, where advisable guarauteeing pricos to growers, taking the necessary measures to secure to growers better prices for better cotton, where desired ginning and marketing cotton and spending money on the promotion of the growing of cotton as compared with other crops.

A Central Office will be located in Westminster to co-ordinate work and to undertake the general direction and control. This office will maintain clcse liaison with the Oversens Governments and the Departments of the Home Government associsted with them, ind will also establish a journal. The Central Office will also select four Trevelling Commissioners who will koep in touch with local development by systematic touring.

Further, the Committee propose engaging a staff for supplementing the stafis of agricultural departinents ovorseas and pioneering. In working any such propossls the greatest stress is laid on the fullest cooperation with the locel agricultural departments. The Committee also propose to assist in providing facilities for training men at the Universities for the various agricultural services abroad; such a staff will be of service to all industries using tropical vegetable products, and it is proposed to enclesvour to co-ordinate theso industries in a common offort for this purpose and to provide funds to increase the University stafis in this country.

The amnual financial requiromenta of the Committeo aro estimated approximately at:- $£ 25,000$ for the executive work, Central Office and Journal; $£ 20,000$ for research stations abroad; $£ 115,000$ for supplementing staffs overseas and pioneering ; $£ 12,000$ for education. To this must be added the commercial handling for which no estimate has been framed, but which will require funds.

-L. M. S.

\section{DEFECTS IN DYEING}

Dr. L. L. Lloyd, in the course of an address before the West Riding Section of the Society of Dyers and Colourists, at Bradford, on the 23rd December, dealt with defects produced by sizing. In some cases, he said, animal size led to defects through careless preparation and through insufficient cleaning to remove the size before dyeing. In flour sizing, the defects were mainly caused by inefficient methods of treatment and unscientific mothods of blending. The grestest difficulty was produced by unskilful blending of materials for antiseptic purposes. The majority of the antiseptic materials contained formaldehyde, and the effect of the formaldehyde was to convert into almost insoluble nodules the little lumps of size on the worp, which rendered uneven dyeing very probsblo. If the trestment were combined with any of the diastatic or tripase preparstions, the possibility of defects was greatly reduced.

Another source of trouble was the use of soluble oils by the warper in order to reduce the time of conditioning. The temperature in crabbing was sufficient to polymerise soluble oil, and he had found that less than one-tenth per cent of oil left on the piece was sufficient to cause patohy dyeing. Fairly level results could be obtained with acid colours, though the dofect would be visible, but with mordent colours the defects became very obvious. Indigo was perfectly level, and indigo bottoming, even to a very light shade, enabled either acid or mordant colours to be used satisfactorily. The cause of the defect was that the conditioning box from which the soluble oil was conveyed to the material was loft in charge of a girl, and he had found in some cases no oil in the box, whilst at other times it was full. If the oiling were regular and constant, he did not think there would be any reason to object to the process.

The Chairman (Mr. H. Jennings) suggested that if they could standardise the sizes and other materisls used in treating goods the dyer would be in a better position to know how to deal with them.

Dr. Lloyd said he did not see why the Society should not be able to co-operate with some other Socioty in order to get sizing standardised.

Mr. G. G. Hopkinson ssid the discussion indicated that there were many faults in the trade which could be obviated by a little co-operation. 